\title{
Reorienting the Principle of Sustainable Development in Investing Policy Utilizing Natural Resources and Energy in Indonesia
}

\author{
Wahyu Nugroho ${ }^{1, *}$ \\ ${ }^{1}$ Universitas Sahid Jakarta, Jl. Prof. DR. Soepomo No.84, RT.7/RW.1, Menteng Dalam, Kec. Tebet, Kota Jakarta Selatan, \\ Daerah Khusus Ibukota Jakarta 12870, Indonesia
}

*Corresponding Author: wahyulaw86@yahoo.com

\section{Article History}

Received 17 July 2021

Accepted 17 January 2022

Available 27 February 2022

\begin{abstract}
The exploitation of natural resources affects environmental damage and does not comply with environmental licensing. This article aims to find out and understand related to development through investments that can achieve people's welfare and analyze the reorientation of sustainable development principles in investing by utilizing pro-environment natural resources. This result is a reorientation of the focus of sustainable development by integrating the activities of the investment policy of natural resources into the economic system and environmental-based budget. The conclusions are; first, the perspective of the Indonesian government in development through investments is not directly proportional to the welfare of the people. Current developments tend to the developmental and anthropocentrism paradigms. Secondly, the principle of sustainable development changes the government's perspective on development that is not environmentally oriented and integrates natural resource investment activities into the economic system or environment-based budgets.
\end{abstract}

Keywords:

sustainable development, natural resources, environmental, energy, investment, economic

\section{Introduction}

The environment is essential for the continuity of human life on earth with various activities that utilize natural resources. At the same time, there are non-biological natural elements as a supporter of ecosystem life. Each country has a program for how development can be utilized for the community's welfare, with no exception economic development through investment in the utilization of natural resources. In a country relying on its policy and economic development on natural resources, there will be a significant problem of natural destruction when there is no balance to the environment, including ecological justice. Indonesia is a country among countries with a wealth of natural resources that can be renewed, such as forests or that can not be restored, for example, mining. Economic development through the ongoing investment by observing the various aspects or principles in sustainable development (Mensah, 2019), namely economic, social and ecological, has undergone massive shifts dominated on economic pillars or increased economic growth (Basiago, 1999). In some countries with developed economies, the environmental regulations applied are pretty strict. In contrast, in developing countries, environmental regulations are still weak, so an integrated monitoring system is needed between institutions electronically and across sectors (Kostakis et al., 2017).

Indonesian economic development based on Constitution 1945 is considered integrated with environmental insight, so we cannot view it partially. In realizing the balance in the financial and 
ecological Constitution, Indonesia is mined by failure to prove environmental damage resulting from economic development activities by not using ecological insight. The balance of economic development with environmental and sustainable sense has been stated in the Indonesian Constitution in Article 33 paragraph (4) of the 1945.

The constituent of the economic development nationally and regions based on the principle of regional autonomy from the provisions of the principle that is closely related to the policy of environmental management in the natural resources sector is the fairness of efficiency containing meaning in the utilization of natural resources is done as efficiently as possible, not to be directed an exploitative action up to environmental damage, then the principle of continuing to pay attention to generations in the future still there is a reserve of natural resources raw materials, as a manifestation of cross-generational justice, while environmental insights containing the meaning of natural resources management has the perspective, knowledge and management practices that are oriented towards the environment. This is where the government has taken place in the orientation of national and local economic development oriented towards the pursuit of economic growth and investment made from natural resources for infrastructure, mining, forestry and coastal activities.

Sustainable development in its journey has a shifting meaning, so it must be re-examined or reoriented its investment utilizing of natural resources. Currently, the earth is in the process of recovering from exploitative to natural resources in the middle "pandemic COVID-19" worldwide in 2020 and demonstrates human behavior in fulfilling the economic needs of unbalanced nature, especially the ruler in running the program and policy through the development of investment in the field of natural resources. During the COVID-19 Pandemic, there is no smoke and clean air pollution from motorized vehicles and exploitation of natural resources that produce waste derived from the dirty industry and environmental damage due to the change of a spatial and land function. It is supposed that the country has stopped various infrastructure projects that utilize natural resources as raw materials. The attitude of the ruler who does not consider the principles of environmental and sustainable insight then spawned a crisis of water, food, energy and forests. Man is like returning to his origin as "homo homini lupus".

Recently, the World Water Development Report 2020 proposed many adaptations and mitigations for the water-climate-energy-food-environment nexus and models: coupling multiple nexus factors waters-climate, water-food, water-energy were developed to link up with the impacts of climate variability and the water, human health, environment and nutrition nexus. However, the inherent complexities and uncertainties are still hindering the understanding of Water, Energy, Food, Biodiversity and Human Health (WEFBH) and the complex relationship between water resources Virtual Water (VW) and other sectors. The VW notion, biodiversity and human health are crisscross ignored in the currently existing famous Water-Energy-Food (WEF) nexus approach. Therefore, incorporating $\mathrm{VW}$, biodiversity and health domains in the nexus assessment as discrete segments aid in gaining a more profound intuition of the influential contribution of the considered sectors on food, water and energy security (Hirwa et al., 2021).

Investment in the use of natural resources, especially for non-renewable energy, tends to ignore the principles of environmentally sound development so that laws and policies are needed to control these activities, especially in energy law. Energy law identifies and analyses the legal issues associated with the exploitation of all the primary and secondary energy sources, where 'exploitation' refers to any stage of the process which involves finding a resource and bringing it to commercial use. It regulates 'the allocation of rights and duties concerning the exploitation of all energy resources between individuals, between individuals and the government, between governments and between states' (Wawryk, 2014).

The perspective of investment-related countries is very anthropocentric to natural resources that impact on environmental damage and do not observe environmental ethics. Environmental licensing instruments are not followed by supervisory functions or licensing processes that contain defect procedures, such as not involving directly affected communities. The reductionist paradigm of natural resources and as an object that must be mastered and utilized for business purposes, here the country is 
in the position of economic growth to scale priorities. At the same time, environmental sustainability is ignored, and there is a contradiction between the economy and the environment.

Various disciplines relate this issue holistically from science to humanities, so that people are holistic to the conditions of the planet earth so damaged by the exploitation of natural resources. In the pandemic conditions of COVID-19 in 2020 this year, countries that have a wealth of natural, in the program and its policies through the development of conscious economics to halt projects made from natural resources, because the earth is recovering from exploitative actions and ecological damage. Indonesia, as one of the countries with a wealth of natural resources, guarantees its citizens to fulfill the rights regulated in the constitution so that infrastructure development and the use of energy as the livelihood of many people must be oriented towards the welfare of the Indonesian people.

The problem statements in this article are: first, whether the Indonesian government's perspective on development through investments that utilize natural resources can achieve the welfare of the people? Second, how does reorientation the principle of sustainable development in investing policy using natural resources that are environmental insight? This research article aims to find out and understand the Indonesian government related to development through investments that utilize natural resources to achieve people's welfare and review and analyze the reorientation of sustainable development principles in investing policy using pro-environment natural resources.

\section{Method}

The substantive area in this study is environmental law. This article utilizes qualitative method within the scope of the Indonesian government related to development through investments that use natural resources to achieve community welfare and examines and analyzes the reorientation of sustainable development principles in investing policies by utilizing natural resources. The author uses secondary data by studying various journal literature books and development relating to the implementation of sustainable development in natural resources in Indonesia.

\section{Analysis and Discussion}

\subsection{The Concept of Sustainable Development in Global and National Developments}

The concept of sustainable development which was internationally developed through the World Commission on Environmental and Development (WCED) report in 1987, what happened at that time was discussing development issues that impacted the environment. Also, it included a SUMMIT (highlevel conference), Rio, in Rio de Janeiro Brazil in 1992. Through the Brundtland report in the World Commission, titled "Our Common Future" or our mutual future, sustainable development has undergone unsustainable development and environmental disaster for ecological damage.

The implementation of the United Nations Conference on Environment and Development (UNCED) in Rio de Janeiro is relevant to environmental governance participation internationally. Civil society in Rio was present as part of the forum with various topics of discussion on the environment, development and poverty issues. The participation of various civil society groups is the basis for Agenda 21 and the Rio agreement. There is a United Nations Commission on Sustainable Development established after the existence of UNCED under the United Nations Economic and Social Council (Backstrand, 2006).

The World Commission on Environment and Development (WCED) requested to formulate a global change agenda by the United Nations General Assembly. In addition, long-term environmental policy measures are proposed so that sustainable development can be implemented in 2000 and beyond. Furthermore, recommends caring for the environment among developing countries through economic and social development by considering the reciprocity between people, resources, environment and development. The global community can solve environmental problems in the long term and 
appropriate efforts are needed to address environmental protection and preservation issues (WCED, 1987).

A WCED report titled "Our Common Future", emphasized the analysis of the relationship between environment and development. The first part of the report raises mutual concern due to environmental damage either because of poverty as well as the development process itself which is ultimately threatening the next day together. The first part presented ideas and strategies towards sustainable development and international economic role. The second part reviewed six challenges together as a focus of WCED study, namely population and human resources about environment and development, food safety, species and ecosystems as a resource for development, the role of energy as an option for the environment and development, as well as urban challenges. In the third part, the need for joint endeavours to manage the co-ownership, peace, security, development and environment, and joint action for legal and institutional changes (Akib, 2016).

Domestic problems in some countries are related to energy supply and consumption, not related to oil exploitation. The energy market was launched small, then developed into industry, coal and separation was carried out nationally, the supply of which was provided by state-owned enterprises. There was a lack of international energy trade before the 1970s and a lack of understanding regarding the environmental impacts across national borders due to the use of energy before the 1960s. There was the exploitation of energy resources and the protection of the environment globally. It was finally before the 1970s, few agreements or regulations were governing the energy market (Wawryk, 2014).

There are three most important concepts: 1) the concept of socio-economic development that goes hand in hand with ecological problems; 2) the concept of the need to ensure the quality of life together; and 3 ) the concept of future generations to ensure the quality of life of the next generation. The concept and principles of sustainable development explain the issues of need and concern for the present and future generations of communities, improving the quality of life and overall equality, protecting and preserving the environment, protecting biodiversity and ecosystems, protecting and conserving natural resources, considers the depletion of non-renewable resources, changes from production and consumption concerning ecosystems, the use of renewable energy and innovative technologies to minimize adverse impacts on the environment, enhance international, national, regional and local networks and collaborations, and build institutions with stakeholders to equate perspectives on sustainable development (Klarin, 2018).

Environmental problems in the case submitted by the United Nations General Assembly in 1995 at the International Court of Justice (ICJ) related to the opinion of the Treatment Advisor or the nuclear weapons case that this issue is an abstraction, but represents the living space, quality of life and human health (ICJ, 1996).

Various achievable environmental goals were set in 1992 to deal with environmental problems. On agenda 21 that has been formulated at the United Nations Conference on Environment and Development, is an action plan to campaign for the principles of sustainable development and has been adopted by various international organizations and countries in national policies (Trebilcock \& Prado, 2014).

The United Nations Conference on Sustainable Development or Rio Plus was held on 20-22 June 2012 in Rio de Janeiro, Brazil. Rio Plus 20 Results is a document of our desired future outcomes adopted through UN General Assembly resolution No. 66/288 dated 27 July 2012. The document states that the establishment of a universal intergovernmental forum builds strength, experience, resources and the existence of an inclusive participation modality from the sustainable development commission (Pramudianto, 2017).

The discussion focused on problems, developments and progress in implementing sustainable development in each country at the Rio conference. The existence of member countries participating in 
the forum is a joint commitment globally to solve development, economic and social problems. These problems can be determined through green economic policies, poverty alleviation and establishing institutions to support sustainable development in each country (UNEP, 2012). In addition, it produced the draft Sustainable Development Goals (SDGs) and the establishment of the Intergovernmental Committee of Experts on Sustainable Development Financing.

The existence of environmental degradation has implications for poverty because of the depletion of natural resources and reduces the basic rights of citizens. There are environmental injustices aimed at the poor and the potential to suffer from policies that do not pay attention to the environment, while natural resources continue to be exploited by the oligarchs. It is necessary to change the paradigm of how natural resources and the environment are valued and regulated, due to the deepening inequality and post-2015 development disorientation. Environmental damage oriented towards non-renewable energy reserves, as well as the existence of ecosystem services for the balance of nature (UNDP, 2014). The principles of sustainable development guide the utilization of natural resources in investment activities in Indonesia. There has been a shift due to environmental damage around natural resources by sector, while the goals of community welfare have not been achieved. People in such categorization do not have a definite size yet. Still, when looking at the communities around natural resources, such as forests, mines, coastal and so forth, their economic condition is a concern. When the philosophical lines are drawn upward, sustainable development principles, pillars and concepts ultimately occur in the antinomy between the economy and the environment or ecology.

The term "ecological" for the first time was introduced by the German biologist Ernst Haeckel in 1869. Although many previous scholars such as Hippocrates, Aristotle and other Greek philosophers had provided descriptions of the ecological qualities, they did not mention ecological terms (Odum, 1993). In the Book of Soemarwoto (1991), etymologically, the word "ecology" comes from the Greek, which is Oikos meaning home or place to live, and logos which means science, so that the terminology of ecology can be interpreted as the science of living beings in his home or can also be interpreted as the science of living Creatures.

Hempel (1996) suggests that the power of economic growth and the power of environmental protection are two things that can be compromised and are more prudent in their application. As Emil Salim suggests sustainable development requires us to manage natural resources with ecological balance. That is, natural resources can be utilized and pay attention to the ecological balance so that they are wise in their use. For this, it is necessary a development approach with environmental development, namely eco-development (Salim, 1996), while Soemarwoto (1999) stated that sustainable development is the balanced implementation of ecological, social and economic pillars.

Various concepts of sustainable development from the Rio conference and into international agreements, raise a fundamental question, is sustainable development the same as sustainability? Dobson (1998) provides a comprehensive view that sustainable development is a conception or theory of environmental sustainability. This is the concept of sustainability which implies a view of something that must be maintained for the future, the balance of humans in the use of nature for the necessities of life. The meaning is the theory of environmental sustainability which argues that certain interpretations of the causes of unsustainability lead to a definite view of solutions to solve sustainability problems that are closely related to environmental insight (Ali, 2001).

According to Surono (2008), the concept of environmentally sound development also mandates that environmental management requires quality and optimal management by using all available resources to achieve the management objectives that have been set. The purpose of natural resource management is not only done without full awareness but "needs-driven", namely the inevitable need to create a good living environment. Similarly, environmental management is no longer just a "reactive" that waits until the problem of the environment is increasingly greater and complex, but it takes the step "proactive" to have the impact of an issue can be prevented as early as possible or at least be able to be asked. 


\subsection{The Perspective of the Indonesian Government in Development through Investments that Utilize Natural Resources}

Sustainable development is constantly evolving and integrated into national laws and regulations in natural resource management in Indonesia. In economic development in Indonesia, we are utilizing natural resources and energy with the principles of environmental insight and sustainability. In the control function, the management of natural resources and energy uses permits as an instrument to prevent pollution and environmental damage.

The constitutionality of policy controlling natural resources by the State must also be used for the maximum welfare of the community. The foothold of the Constitution is then lowered into several legislations governing the activities of sectoral natural resources to invest in forestry, mining, oil and gas, plantations and its management authority related to central government relations and local governments. Economic development in the Indonesian Constitution is oriented to economic interests and an investment in economic development. It also has an instrument for controlling pollution and or environmental destruction to have environmental insight and sustainability development by utilizing natural resources as the raw material of the national economy has environmental impacts, both pollution to environmental damage, to consider aspects of environmental insight, apply the principles as the provisions of Article 33 paragraph (4) Constitution 1945 for the implementation of economic democracy. It heavily depends on the perspective of a country on natural resources. When the natural resources are dominated by investor interests to make the natural resources become the primary source of the national economy, there will be an imbalance of ecosystem available in nature, friction with society and local wisdom with its management policy. This includes the regional autonomy regime by increasing investment; hence, it must be integrated with environmentally sound environmental policies.

In the view of Witter and Birner (2005), some streams affect the conservation of natural resources, including Conservationists, Ecological Populism and Developmentalism. The first thought flow (conservationists) argued that it needed a legally protected area and was not disturbed by human activities to realize ecological balance. It is essentially a notion that the locals threaten natural resource conservation efforts. This flow believes that natural sciences no longer need to be debated. The second thought stream, ecological populism, states that indigenous and local people are the most significant insurers to be protected. They also can conserve natural resources better than the government. The ecopopulist flow rejects private presence and conservation practitioners that deny indigenous and local communities. Their views reject the orthodox view of the social and natural sciences but favour an appreciation of local knowledge. Then the third flow (developmentalism) has the assumption that natural resources are caused by poverty so that the handling and policies are more character development. This genre assumes that the ecological populism is in favour of local communities and the environment, while the conservationists are considered not concerned about the poverty issues of the community around conservation forests.

Based on the views of Witter and Biner, the development of natural resource management and the use of non-renewable energy in Indonesia is dominated by the anthropocentrism paradigm. The national economic development that rests on the management of natural resources has resulted in the impact of damage and or pollution of the environment with the rapid growing investment in the forestry sector, mineral and coal mining, oil palm plantations and so forth, the government makes various regulations to meet the needs of capital owners and guarantees the law in running a business that utilizes nonrenewable natural resources.

An example of government policy through the implementation of the job creation law has shifted the principle of sustainable development-oriented towards economic improvement and ignores the principles of environmental insight. The paradigm of the state is likely to be developmentalism with various policies to meet the needs of investment and infrastructure projects that impact the agrarian sector, including the decline in quality and land function, land conflicts, errors in spatial planning, or the use of spatial and environmental damage (Gustafsson et al., 2019; Oliveira et al., 2018). At this 
point, there is a paradox between a policy of economic paradigm and a sustainable environment. Gopel (2016) said that the economic paradigm is profit-oriented and increases investment, but it does not consider environmental and sustainable issues. The hegemony of the economic paradigm depends on the authorities to balance the economy and the environment.

Policies in the agrarian sector correlated with the management of natural resources as the main capital of development are not managed sustainably, but instead exploited to pursue economic growth targets. Therefore, the legal instrument used to support the economic development paradigm as mentioned above is likely to be centralistic, sectoral, favoring to large capitalists (capital oriented), exploitative and repressive nuance using a security approach (Nurjaya, 2017). Amendment Article 331945 Constitution of the Republic of Indonesia is a formulation that regulates the economic principles of the state that is being built today must be considered as a comprehensive integral, by bringing together economic, social and environmental issues.

Governments may use its authorities to manage the natural resources, notwithstanding the principles of environmental and sustainable insight. The establishment of legal policies and products governing investment in natural resources (such as mineral and coal mining, forestry, oil palm, oil and gas and other non-renewable natural resources) will be increasingly drained. At the same time, the Constitution provides a mandate to apply the principle of equitable efficiency, meaning that using as efficiently as possible fairly or proportionally as needed, rather than conducting massive exploitation that harms local community groups. The state's goal for the community's welfare does not have a positive impact on improving the economy of local communities in natural resource areas.

The Indonesian government's perspective through investing in the use of natural resources and using non-renewable energy does not have environmental insight. Central and regional governments make shelter regulations behind the meaning of mastering the state, to fulfill investment needs, or ensure legal certainty for capital owners, a change of rules on national and regional spatial.

\subsection{Reorientation of the Principle of Sustainable Development in the Investment Utilizing Natural Resources Environmental Insight}

Reorientation is a review to determine attitudes. As mentioned earlier, the study serves the examination on the application of sustainable development principles in investment of natural resources and nonrenewable energy. Various types of investment activities in the field of natural resources must be reviewed for the use and implementation of sustainable development because the interests of investments that have an impact on environmental damage are increasingly dominant.

The government may not be aware of the principle of sustainable development, in which there are elements of environmental insight and meaning of cross-generation justice. The paradigm of anthropocentrism has shifted the country's policy to control natural resources, but the welfare of the people depends on how the government manages nature. Anthropocentrism states that human prosperity in the future is very dependent on nature. The universe has no intrinsic value, while future generations have the rights to be used to protect the planet and ecosystems (Spahn, 2018).

Investing in Indonesia is still utilizing natural resources to run development with the goal of the prosperity of people. Countries that have authority in the management of natural resources consider the interests of the investment economy and the welfare of the people as a manifestation of economic democracy. Still, there is a principle of environmental insight as a form of environmental democracy considered to run its development. State reorientation in carrying out the mandate of the Constitution becomes essential because, in its implementation, there has been a shift in environmental democracy principles to the interests of capital owners and the pursuit of state revenues, and not directly proportional to the welfare of the people. 
In the context of the administration of natural resources, not only for the benefit of economic commodities to achieve the acceptance of the country alone, but also the social and environmental aspects of the environment become an aspect that cannot be separated in the exploitation of natural resources. Related to environmental aspects, this is not only the principle of natural resources administration, but this aspect even goes into the process of the administration itself. In the framework of the administration of natural resources, administrative instruments and environmental technologies are integrated into the process. Each natural resource administration activity must meet the Environmental Impact Analysis (AMDAL), Environmental Management Efforts-Environmental Monitoring Efforts (UKL-UPL) and Environmental Licences (Redi, 2014). Also, there is Strategic Environmental Studies (KLHS) compiled by governments and local governments that integrate with the spatial system, to ensure that the principle of sustainable development has been implemented by the Government with a variety of permits given to the private for its investment in the field of natural resources.

Various kinds of investments in Indonesia by utilizing natural resources, including extractive activities in mineral mining and coal, electricity sector activities, oil and gas, geothermal, forestry and plantation, are the potential damage and or pollution of the environment. Licensing of business activities will be followed by integrated supervision. Supervision is part of law enforcement, primarily the actions of state administration through various administrative sanctions regulated by law.

The shifting principle of sustainable development is because it does not integrate strategic environmental studies into the national spatial system to the spatial area, including the economic calculations for environmental losses from investments in the natural resources field. The appropriate control instruments of the state are not executed and have an impact on the violation of natural resource investments. A nonfunctioning surveillance system in the context of environmental and environmentalbased economic instruments that should be integrated into production costs as stipulated in Article 14 national environmental regulation in Indonesia.

The reorientation of the principle of sustainable development begins with the government's shift of paradigm or perspective in environmental policy that utilizes natural resources. The transition can be done by using the ecocentrism paradigm, prioritizing aspects of environmental preservation in its investments that use natural resources. The country has a realization that the environment and natural resources are the life of the ecosystem where humans are part of the ecosystem that requires other environmental elements, including the sustainability of generations in the future. In forest utilization and mineral and coal mining, always connect all components in the environment, especially ecosystems that are affected by natural resource development activities. The government ensures that business entities or corporations have guarantees in the licensing process until the implementation of business activities on the utilization of natural resources, can consider all affected components in the ecosystem. Next, the reorientation of the principle of sustainable development in investment by utilizing natural resources the environmental insight should be done by integrating the activities of the acquisition of natural resources into the economic system and environmental based budget, followed by supervision of environmental licensing instruments. Environmental policy by Governments and local governments under Law No. 32 the year 2009 on Environmental Protection and Management, and Law Number 23 of 2014 concerning Regional Government which is the authority to conduct guidance and supervision.

\section{Conclusion}

Based on the results of the research in this article, the author concludes that the paradigm of the Indonesian government in economic development and investment using natural resources and energy does not yet have a balance with the development goal, namely for the welfare of the people. The current government's perspective is anthropocentric, so that the natural resources, energy and environment are exploited only for business purposes. This results in the impact of environmental damage and pollution along with the growth of investment in the forestry sector, mineral and coal mining and oil palm 
plantations with non-renewable energy characteristics. Changes in policies and regulations in the field of spatial planning have shifted the principles of environmentally sound development.

The Indonesian constitution mandates the government to control natural resources and manage nonrenewable energy, but must pay attention to the principles of environmental insight and sustainability. In making future policies and legal products, an ecocentric paradigm is needed, so that the principles of environmental insight and sustainability are accommodated in the formation of laws and regulations in the field of natural resources and energy, with an orientation towards environmental and social justice.

The reorientation of the principle of sustainable development in the investment in natural resources and energy to the environment insight is done by integrating natural resources investment activities into the economic system and environmental-based budgets, to be followed by supervision of environmental licensing instruments.

\section{References}

Akib, M. (2016). Hukum lingkungan perspektif global dan nasional (Ed. Rev. Cet.3). PT Rajawali Pers.

Ali, A. (2001). A conceptual framework for environmental justice based on shared but differentiated responsibilities. CSERGE Working Paper EDM (01-02), 6.

Backstrand, K. (2006). Democratizing global environmental governance? Stakeholder democracy after the world summit on sustainable development. European Journal of International Relations, 12(4), 470. https://doi.org/10.1177/1354066106069321

Basiago, A. (1999). Economic, social, and environmental sustainability in development theory and urban planning practice. The Environmentalist, 19, 150-151.

Gopel, M. (2016). The great mindshift: How a new economic paradigm and sustainability transformations go hand in hand. Springer Open \& Wuppertal Institute, AFES-PRESS e.V.

Gustafsson, S., Hermelin, B., \& Smas, L. (2019). Integrating environmental sustainability into strategic spatial planning: the importance of management". Journal of Environmental Planning and Management, 62(8), 1321-1338. https://doi.org/10.1080/09640568.2018.1495620

Hirwa, H. (2021). Insights on water and climate change in the Greater Horn of Africa: Connecting virtual water and water-energy-food-biodiversity-health nexus. Sustainability, 13, 6483. https://doi.org/10.3390/su13116483

International Court of Justice (ICJ). (1996). Advisory opinion legality of the threat or use nuclear weapons case: 19.

Klarin, T. (2018). The concept of sustainable development: From its beginning to the contemporary issues. Zagreb International Review of Economics \& Business, 21(1), 76.

Kostakis, I., Lolos, S., \& Sardianou, E. (2017). "Foreign direct investment and environmental degradation: Further evidence from Brazil and Singapore". Journal of Environmental Management and Tourism, 8(1), 46. https://doi.org/10.14505/ jemt.v8.1(17).04

Mensah. J., (2019). Sustainable development: Meaning, history, principles, pillars, and implications for human action: Literature Review. Cogent Social Sciences, 5-6. https://doi.org/10.1080/23311886.2019.1653531

Nurjaya, I. N. (2007). Pengelolaan sumber daya alam dalam perspektif otonomi: Tinjauan hukum dan kebijakan", Jurnal Suloh, 5(1), 1.

Odum, E. P. (1993). Dasar-dasar ekologi, translated by Tjahjo Samingan. Gadjah Mada University Press.

Oliveira, E., Tobias, S., \& Hersperger, A. M. (2018). Can strategic spatial planning contribute to land degradation reduction in urban regions? State of the art and future research, Sustainability, 10(949), 1-23. https://doi.org/10.3390/su10040949

Pramudianto, A. (2017). Hukum lingkungan internasional, (Ed. I). Rajawali Pers.

Redi, A. (2014). Hukum sumber daya alam dalam sektor kehutanan. Sinar Grafika.

Romeiro, A. R. (2012). Sustainable development: An ecological economics perspective, Estudos Avançados, 26(74), 65-67. https://doi.org/10.1590/S0103-40142012000100006

Soemarwoto, O. (1991). Ekologi, lingkungan hidup dan pembangunan. Djambatan. 
Soemarwoto, O. (1999). Pembangunan berkelanjutan. Penerbit Alumni.

Spahn, A. (2018). "The first generation to end poverty and the last to save the planet?"-Western individualism, human rights, and the value of nature in the ethics of global sustainable development, Sustainability, 10(6), 5-10. https://doi.org/10.3390/su10061853

Surono, A. (2008). Penyelesaian konflik sumber daya hutan secara kolaboratif (kemitraan). Fakultas Hukum Universitas al-Azhar Indonesia.

Trebilcock, M. J. \& Prado, M. M. (2014). Advanced introduction law and development. Edward Elgar Publishing.

United Nations Development Programme/UNDP. (2014). Environmental justice comparative experience in legal empowerment.

Witter, H. \& Birner, R. (2005). Between conservation, eco-populism, and developmentalism Discourse in biodiversity policy in Thailand and Indonesia”, CAPRI Working Paper No.37, International Food Policy Research Institute, p. 1.

Wawryk, A. (2014), International energy law: an emerging academic discipline. In P. Babie \& P. Leadbeter, Law as Change: Engaging with the life and scholarship of Adrian Bradbrook (pp. 223255). University of Adelaide Press. https://www.jstor.org/stable/10.20851/j.ctt1sq5xcn.14 